with exogenous surfactant, the premature rabbit lung can be ventilated adequately with $\mathrm{HFO}$ at a comparatively low mean airway pressure, and that at these particular experimental conditions surfactant replacement effectively prevents the development of epithelial lesions.

Acknowledgments. We are indebted to Dr. Charles A. Bryan, Toronto, for constructive criticism during pilot experiments preceding this study, and Dr. Stellan Bygdeman, Stockholm, for valuable advice concerning the interpretation of the ECG recordings.

\section{REFERENCES}

1. Bland RD, Sedin EG 1983 High frequency mechanical ventilation in the treatment of neonatal respiratory distress. Int Anesthesiol Clin 21:125-147

2. Finlay-Jones J-M, Papadimitriou JM, Barter RA 1974 Pulmonary hyaline membrane: light and electron microscopic study of the early stage. J Pathol 112:117-124

3. Gregory GA, Kitterman JA, Phibbs RH, Tooley WH, Hamilton WK 1971 Treatment of the idiopathic respiratory distress syndrome with continuous positive airway pressure. N Engl J Med 284:1333-1340

4. Hughes JMB, Hoppin FG, Mead J 1972 Effect of lung inflation on bronchiolar length and diameter in excised lungs. J Appl Physiol 32:25-35
5. Jobe A 1984 Respiratory distress syndrome-new therapeutic approaches to a complex pathophysiology. Adv Pediatr 30:93-130

6. Lachmann B, Grossmann G, Freyse J, Robertson B 1981 Lung-thorax compliance in the artificially ventilated premature rabbit neonate in relation to variations in inspiration:expiration ratio. Pediatr Res 15:833-838

7. Lachmann B, Grossmann G, Nilsson R, Robertson B 1979 Lung mechanics during spontaneous ventilation in premature and fullterm rabbit neonates. Respir Physiol 38:283-302

8. Lachmann B, Grossmann G, Nilsson R, Robertson B 1981 Effect of supplementary surfactant on in vivo lung mechanics in the premature rabbit neonate. Eur J Pediatr 136:173-179

9. Mautone AJ, lorio P, Moss IR, Scarpelli EM 1982 Use of high frequency oscillation in immature lambs at birth. Pediatr Res 16:356A

10. Nilsson R, Grossmann G, Robertson B 1978 Lung surfactant and the pathogenesis of neonatal bronchiolar lesions induced by artificial ventilation. Pediatr Res 12:249-255

11. Nilsson R, Grossmann G, Robertson B 1980 Bronchiolar epithelial lesions induced in the premature rabbit neonate by short periods of artificial ventilation. Acta Pathol Microbiol Scand (A) 88: 359-367

12. Slutsky AS, Brown R, Lehr J, Rossing T, Drazen JM 1981 High-frequency ventilation: a promising new approach to mechanical ventilation. Med Instrum 15:229-233

13. Strang LB 1977 Neonatal respiration. Physiological and clinical studies. Blackwell Scientific Publications, Oxford, p 69

14. Takada $Y$, Kobayashi $T$, Kataoka H, Murakami S, Kokubo M, Yoshida T 1983 Effects of surfactant supplement by high frequency jet ventilation in lung lavaged rabbits. J Jpn Med Soc Biol Interface 14:67-74

\title{
Rheology of Fetal and Maternal Blood
}

\author{
WALTER H. REINHART, STUART J. DANOFF, ROBERT G. KING, AND SHU CHIEN \\ Division of Circulatory Physiology and Biophysics, Department of Physiology, and Division of Neonatal \\ Medicine, Department of Pediatrics, Columbia University College of Physicians and Surgeons,
} New York, New York 10032

\begin{abstract}
Rheological parameters were measured in 10 pairs of mothers and newborns. Whole blood viscosity was similar despite a higher fetal hematocrit $(47.0 \pm 5.1$ versus $35.5 \pm 12.0 \%$, mean $\pm \mathrm{SD}, p<0.05)$. When the hematocrit of the suspension of red cells in plasma was adjusted to $45 \%$, the viscosity was significantly lower in the fetal blood over a wide range of shear rates $(0.52-208$ $\mathrm{s}^{-1}$ ). The main reason for the lower viscosity in the fetal blood was the lower plasma viscosity as compared to the maternal blood $(1.08 \pm 0.05$ versus $1.37 \pm 0.08$ centipoise, $p<0.05$ ); this in turn was attributable to a lower total plasma protein concentration $(4.74 \pm 0.71$ versus $6.47 \pm$ $0.64 \mathrm{~g} / \mathrm{dl}, p<0.05)$. All protein fractions were lower in the fetal plasma. The assessment of red cell deformability by filtration through polycarbonate sieves revealed that the resistance of a fetal red cell was three times higher than that of a maternal red cell in a $2.6-\mu \mathrm{m}$ pore, but there was no significant difference in resistance for these red cells in 6.9- $\mu \mathrm{m}$ pores. This higher filtration resistance of fetal red
\end{abstract}

Received November 4, 1983: accepted July 6, 1984

Correspondence may be addressed to Dr. S. Chien, Department of Physiology, Columbia Medical Center, 630 West 168th Street, New York, NY 10032.

This research was supported in part by United States Public Health Service Research Grant HL-16851 from the National Heart, Lung, and Blood Institute, the Schweizerische Stiftung fuer Medizinisch-Biologische Stipendien, and the Heart Research Foundation, New York. cells through the small pores was mainly due to their large volume $(115.4 \pm 10.8$ versus $93.5 \pm 5.9 \mathrm{fl}, p<0.001)$. Measurements on membrane-free hemoglobin solutions indicated that the internal viscosity of these two types of red cells was not different. We conclude that in fetal blood the higher hematocrit and the presence of larger red cells, which cause impaired passage through pores $<5 \mu \mathrm{m}$, are counterbalanced by a decreased plasma viscosity, resulting in a whole blood viscosity comparable to that of adults. (Pediatr Res 19:147-153, 1985)

\section{Abbreviations}

Hct, hematocrit

$\mathrm{RBC}$, red blood cell

WBC, white blood cell

$\mathrm{MCV}$, mean corpuscular volume

MCH, mean corpuscular hemoglobin

MCHC, mean corpuscular hemoglobin concentration $\mathbf{c P}$, centipoise

Hyperviscosity syndrome in neonates is a serious condition, which may cause congestive heart failure, respiratory distress, and cyanosis $(13,24)$, cerebral infarction (2) and necrotizing 
enterocolitis (15). It occurs in approximately $5 \%$ of all newborn infants (33). The etiology seems to be multifactorial (24), with polycythemia as a major factor $(21,24,33)$.

It has been claimed that newborns have a higher whole blood viscosity than adults $(3,11,21)$. Recently, however, Riopel et al. (31) found a lower blood viscosity in newborns. These findings prompted us to study the rheological properties of fetal and maternal blood in detail.

\section{MATERIALS AND METHODS}

Ten pairs of mothers and their newborn infants were studied. Informed consent was obtained from the mother. All pregnancies were at full gestational term, and elective cesarean section was performed. Prior to anesthesia (general or epidural), $30 \mathrm{ml}$ of the maternal blood was drawn from an antecubital vein into Vacutainers containing heparin. Cord blood was obtained within 5 min after removal of the placenta from the uterus by drawing 30 $\mathrm{ml}$ from a clamped umbilical vein into Vacutainers containing heparin.

The Hct was measured in duplicate by the microhematocrit method. RBC and WBC counts were performed in a Coulter Counter (Coulter Electronics, Hialeah, FL). The Hb concentration was determined by the cyanmethemoglobin method, measuring the light absorption at a wavelength of $540 \mathrm{~nm}$. The MCV, $\mathrm{MCH}$, and $\mathrm{MCHC}$ were calculated from Hct, RBC count, and $\mathrm{Hb}$ concentration. The total plasma protein concentration was measured by using a refractometer $(25)$. Plasma protein fractions were analyzed by means of electrophoresis. Plasma fibrinogen concentration was determined by the method of Ratnoff and Menzie (28).

The morphology of fetal and maternal red cells was studied in the last four pairs. Fresh samples were fixed in $1 \%$ glutaraldehyde in cacodylate buffer $\left(\mathrm{pH} 7.4,4^{\circ} \mathrm{C}\right.$ ) and postfixed in $2 \% \mathrm{OsO}_{4}$. Specimens for scanning electron microscopy (JSM-25, JEOL Corp., Peabody, MA) were dehydrated in ascending ethanol series, air-dried, and coated with gold-palladium. For transmission electron microscopy (model EM 9, Carl Zeiss, West Germany), the specimens were embedded in Epon. Thin sections were prepared and stained with $2 \%$ uranyl acetate and lead citrate. Some specimens were postfixed, prior to embedding, in $\mathrm{OsO}_{4}$ containing $0.1 \%$ ruthenium red as an extracellular marker. Measurements on paper prints of electron micrographs were made with the aid of a magnifying precision scale (Scale Lupe, Peak, Brookstone Comp., Peterborough, NH).

Viscosity measurements were made with a Couette viscometer of high precision (7) at $37^{\circ} \mathrm{C}$. It consists of two concentric cylinders separated by a uniform annular gap of $960 \mu \mathrm{m}$, which contains the sample. The inner cylinder can be rotated at constant speeds, with corresponding shear rates of $0.05-208 \mathrm{~s}^{-1}$. The torque transmitted through the sample to the outer cylinder is balanced by a magnetic countertorque through an electronic feedback system. The viscosity is calculated from the rotational speed, the torque value, and a geometrical conversion factor. For the viscosity measurement of suspensions of RBCs in plasma at a hematocrit of $45 \%\left(\eta_{\mathrm{P} 45}\right)$, whole blood was centrifuged for 5 min at $1500 \times g$, the buffy coat was removed, and the packed RBCs were mixed with the appropriate amount of plasma. For the determination of the viscosity of suspensions of RBCs in Ringer's solution at a hematocrit of $45 \%\left(\eta_{\mathrm{R} 45}\right)$, the red cells were washed 3 times in Ringer's solution containing $145 \mathrm{mM} \mathrm{NaCl}$, $4 \mathrm{mM} \mathrm{KCl}, 2.2 \mathrm{mM} \mathrm{CaCl}_{2}, 5.5 \mathrm{mM}$ dextrose, and $0.5 \mathrm{~g} / \mathrm{dl}$ bovine albumin, adjusted to pH 7.4 with $0.1 \mathrm{~N}$ Tris buffer. The Ringer's solution had been prefiltered through $0.2-\mu \mathrm{m}$ Millipore filters.

Red cell deformability was measured with a microsieving method. Red cells were washed three times in the Ringer's solution (see above). The washed RBCs were resuspended in the Ringer's solution to a hematocrit of $10.0 \%$. Red cell filtration was performed at $37^{\circ} \mathrm{C}$. The RBC suspension was pumped at a constant flow rate of $0.82 \mathrm{ml} / \mathrm{min}$ through polycarbonate filters (Nuclepore Corp., Pleasanton, CA) with different pore sizes (nominal diameters of 3,5 , and $8 \mu \mathrm{m}$ ). The mean pore diameter and the pore density, as determined by scanning electron microscopy, were respectively $2.6 \pm 0.2 \mu \mathrm{m}$ and $23.6 \times 10^{3} / \mathrm{mm}^{2}$ for nominal $3-\mu \mathrm{m}$ filters, $4.5 \pm 0.6 \mu \mathrm{m}$ and $4 \times 10^{3} / \mathrm{mm}^{2}$ for nominal $5-\mu \mathrm{m}$ filters, and $6.9 \pm 0.8 \mu \mathrm{m}$ and $1 \times 10^{3} / \mathrm{mm}^{2}$ for nominal $8-\mu \mathrm{m}$ filters. The same batch of filters was used throughout the study. The filtration pressure $(P)$ was recorded as a function of time $(t)$ using a pressure transducer (model MP 4514, Validyne Engineering Corp., Northridge, CA). Before the measurement of a RBC suspension, Ringer's solution was pumped through the filter and the pressure recorded $\left(P_{0}\right)$. Filtration of a RBC suspension gave an initial pressure reading $\left(P_{i}\right)$, followed by a further rise in pressure with time. The ratio $P_{i} / P_{0}$ was calculated; it reflects the relative filtration resistance of the $\mathrm{RBC}$ suspension. The relative resistance of an individual $\mathrm{RBC}$ $(\beta)$, i.e. the ratio of the resistance in a pore bearing a red cell to that in a pore filled with Ringer's solution alone, was computed (34):

$$
\beta=\left[\frac{P_{i}}{P_{0}}-1\right] \frac{V}{h}+1
$$

where $V$ is the ratio of RBC volume to the pore volume and $h$ is the fractional volume of RBCs in suspension. The rising pressure after $P_{i}$ reflects plugging of pores by cells (either RBCs or WBCs), which cannot pass the filter. It occurs regularly with $2.6-\mu \mathrm{m}$ pores and only occasionally with $6.9-\mu \mathrm{m}$ pores. The slope of the curve, corrected for $P_{0}$, was calculated as a measure of plugging $\left(K_{1}\right.$, Ref. 10).

For the assessment of the internal viscosity $\left(\eta_{i}\right)$ of RBCs, membrane-free hemoglobin solutions were prepared. The RBCs were washed three times with Ringer's solution (see above) and centrifuged at $1,500 \times g$ for $10 \mathrm{~min}$. The supernatant was removed and the packed red cells were lysed with toluene under vigorous stirring for $10 \mathrm{~min}$. The suspension was transferred to cellulose nitrate centrifuge tubes and centrifuged at $30,000 \mathrm{rpm}$ for $30 \mathrm{~min}$. After the removal of the toluene, the solutions were frozen at $-20^{\circ} \mathrm{C}$. In the frozen state, the layer with membrane debris overlaying the hemoglobin solution was cut off. The hemoglobin solution was then thawed at room temperature. The hemoglobin concentration of the melted solution was measured (see above), adjusted to $31 \mathrm{~g} / \mathrm{dl}$ by adding the appropriate amount of $\mathrm{H}_{2} \mathrm{O}$, and kept air-tight in a syringe. The viscosity of the hemoglobin solutions was measured in a Weissenberg rheogoniometer with a cone-plate geometry at $25^{\circ} \mathrm{C}(9)$. The rheogoniometer was preferred over the Couette viscometer because it allowed measurements with smaller samples (about $3 \mathrm{ml}$ ).

For statistical analysis, Student's $t$ test for paired data was used. The results on plasma viscosity and proteins were analyzed with a one-way analysis of variance.

\section{RESULTS}

The hematological parameters of the mothers and their newborn infants are given in Table 1. Newborns had higher hematocrit, hemoglobin concentration, and white cell count, whereas the red cell count was not different from that of the mothers. The red cell indices revealed larger values for the MCV and $\mathrm{MCH}$ in newborns, but their MCHC was slightly lower.

The apparent viscosity of whole blood is shown in Figure 1. Although the newborns had a much higher hematocrit, the viscosity of their whole blood was very similar to that of the mothers at shear rates above $5 \mathrm{~s}^{-1}$. At lower shear rates, the viscosity of the fetal blood tended to be lower, although the difference was not statistically significant. When the hematocrit was adjusted to $45 \%$ (Fig. 2), the fetal blood was significantly less viscous over a range of shear rate from 0.52 to $208 \mathrm{~s}^{-1}$. The 
Table 1. Hematological values (mean $\pm S D, n=10$ )

\begin{tabular}{lcc} 
& Mothers & Newborns \\
\hline Hematocrit $(\%)$ & $35.5 \pm 12.0$ & $47.0 \pm 5.1^{*}$ \\
Red cell count $\left(10^{6} / \mu \mathrm{l}\right)$ & $4.06 \pm 0.39$ & $4.07 \pm 0.40$ \\
Hemoglobin $(\mathrm{g} / \mathrm{dl})$ & $12.8 \pm 1.6$ & $15.0 \pm 1.8^{*}$ \\
Mean corpuscular volume $(\mathrm{fl})$ & $93.2 \pm 5.9$ & $115.4 \pm 10.8 \dagger$ \\
$\begin{array}{l}\text { Mean corpuscular hemoglobin } \\
\quad(\mathrm{pg})\end{array}$ & $31.7 \pm 2.8$ & $35.4 \pm 1.0^{*}$ \\
$\begin{array}{l}\text { Mean corpuscular hemoglobin } \\
\quad \text { concentration }(\mathrm{g} / \mathrm{dl})\end{array}$ & $33.3 \pm 1.0$ & $31.9 \pm 0.6 \dagger$ \\
White cell count $\left(10^{3} / \mu \mathrm{l}\right)$ & $8.43 \pm 2.91$ & $14.94 \pm 4.83 \dagger$
\end{tabular}

\footnotetext{
$* p<0.05$.

$\dagger p<0.001$
}

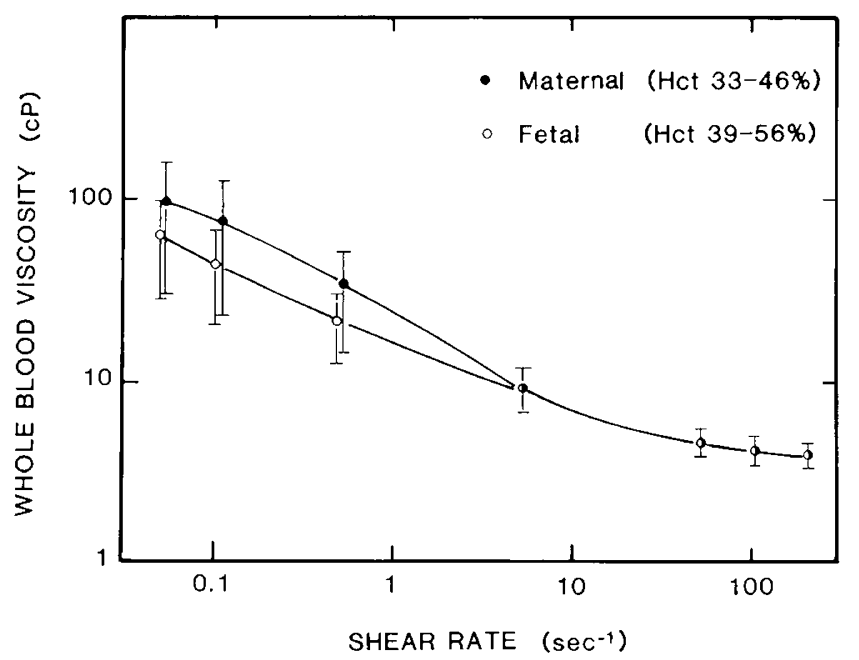

Fig. 1. Log-log plot of the viscosity of whole blood (ordinate, values in centipoise, mean $\pm \mathrm{SD}$ ) from 10 mothers and their newborns versus shear rate (absciss $a)$. Measurements were made with a Couette viscometer at $37^{\circ} \mathrm{C}$.

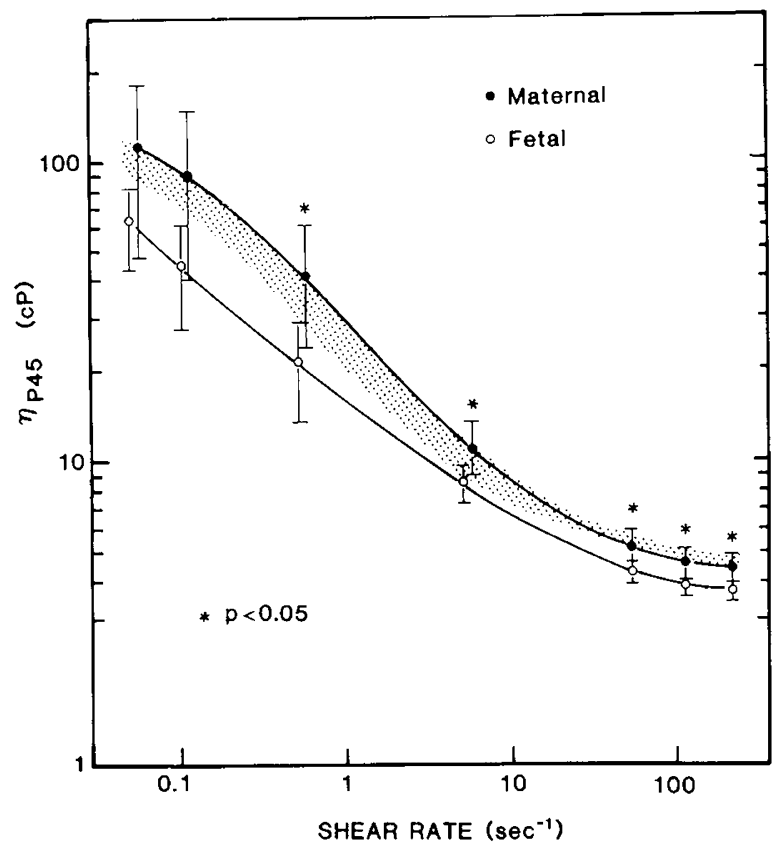

Fig. 2. Log-log plot of the viscosity of maternal and fetal red cells in plasma at $45 \%$ hematocrit ( $\eta_{\mathrm{P} 45}$ on ordinate, mean $\pm \mathrm{SD}, n=10$ ) versus the shear rate (absciss(i). Measurements were made with a Couette viscometer at $37^{\circ} \mathrm{C}$. The shaded area represents the normal range of nonpregnant females $(n=10$, mean $\pm \mathrm{SD})$. viscosity of the maternal blood fell in the range obtained for normal, nonpregnant females.

When washed red cells were resuspended in Ringer's solution at a hematocrit of $45 \%$, the viscosity was much lower than $\eta_{\mathrm{P} 45}$ (Fig. 3). At shear rates above $100 \mathrm{~s}^{-1}$, the viscosity of fetal RBCs in Ringer's solution remained lower than that of maternal RBCs $(p<0.05)$, whereas at shear rates below $10 \mathrm{~s}^{-1}$ the suspension of fetal RBCs showed a tendency towards higher values than maternal RBCs.

The plasma viscosity is given in Table 2 . It is significantly lower for the newborns when compared to their mothers or nonpregnant females. Plasma viscosity correlated best with the total plasma protein concentration (Fig. 4). The individual protein fractions also correlated with the plasma viscosity. The strongest correlation was found for $\alpha_{2}$-globulins $(r=0.830, p<$ $0.001), \alpha_{1}$-globulins $(r=0.804, p<0.001)$ and fibrinogen $(r=$ $0.758, p<0.001)$, with the weakest one for albumin $(r=0.622$, $p<0.005)$ and $\gamma$-globulins $(r=0.594, p<0.01)$. Compared to nonpregnant controls, the mothers had a slightly higher plasma viscosity, which could be due to the higher $\alpha$-globulin concentrations.

The relative filtration pressures of $\mathrm{RBC}$ suspensions $\left(P_{i} / P_{0}\right)$ were comparable for maternal and fetal RBCs through $6.9-\mu \mathrm{m}$ pores $(1.96 \pm 0.42$ and $1.88 \pm 0.38$, respectively) and $4.5-\mu \mathrm{m}$ pores $(2.03 \pm 0.23$ and $2.10 \pm 0.38$, respectively). Filtration through the $2.6-\mu \mathrm{m}$ pores gave a much higher $P_{i} / P_{0}$ for fetal RBCs $(62.4 \pm 13.8)$ compared to maternal RBCs (25.2 \pm 15.9 , $p<0.001)$. For $2.6-\mu \mathrm{m}$ pore filters, a positive correlation between

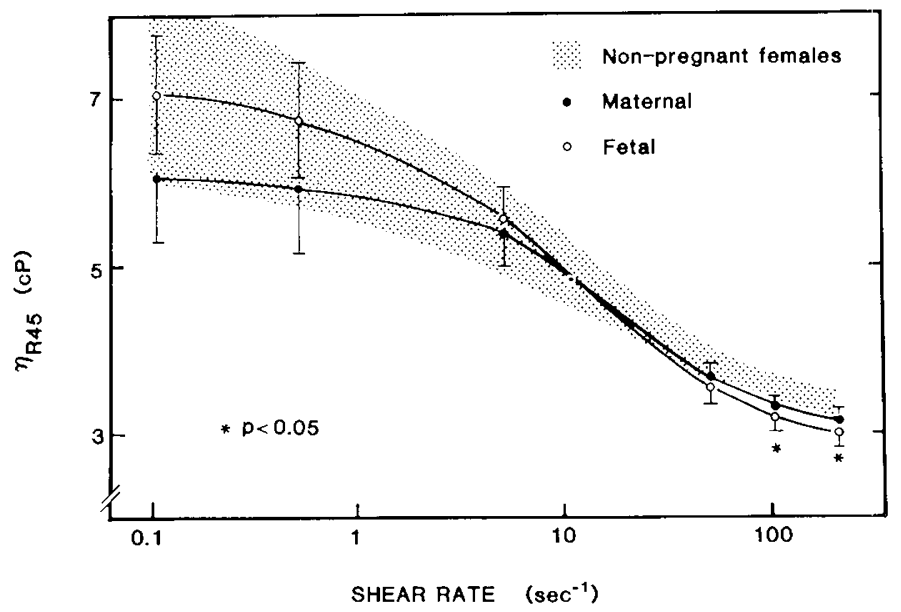

Fig. 3. Semilogarithmic plot of the viscosity of red cells in Ringer's solution at $45 \%$ hematocrit ( $\eta_{\mathrm{R} 45}$ on ordinate, mean $\pm \mathrm{SD}, n=10$ ) versus the shear rate (abscissa). Measurements were made with a Couette viscometer at $37^{\circ} \mathrm{C}$. The shaded area represents the normal range for nonpregnant females $(n=15$, mean $\pm \mathrm{SD})$.

Table 2. Plasma viscosity and proteins (mean $\pm S D, n=10$ )

\begin{tabular}{lccc}
\hline & $\begin{array}{c}\text { Nonpregnant } \\
\text { females }\end{array}$ & Mothers & Newborns \\
\hline Plasma viscosity $(\mathrm{cP})$ & $1.30 \pm 0.04^{*}$ & $1.37 \pm 0.08$ & $1.08 \pm 0.05^{*}$ \\
Total plasma protein & $7.21 \pm 0.34^{*}$ & $6.47 \pm 0.64$ & $4.74 \pm 0.71^{*}$ \\
$\quad$ & & & \\
$\quad$ F/dl) & & & \\
Fractions (g/dl) & $4.28 \pm 0.70^{*}$ & $3.49 \pm 0.46$ & $3.00 \pm 0.54$ \\
$\quad$ Albumin & $0.21 \pm 0.04^{*}$ & $0.31 \pm 0.09$ & $0.18 \pm 0.06^{*}$ \\
$\alpha_{1}$-Globulin & $0.66 \pm 0.13^{*}$ & $0.80 \pm 0.18$ & $0.34 \pm 0.10^{*}$ \\
$\alpha_{2}$-Globulin & $0.66 \pm 0.18$ & $0.69 \pm 0.25$ & $0.29 \pm 0.10^{*}$ \\
$\beta_{1}$-Globulin & $0.39 \pm 0.23^{*}$ & $0.24 \pm 0.10$ & $0.08 \pm 0.04^{*}$ \\
$\beta_{2}$-Globulin & $0.67 \pm 0.25$ & $0.72 \pm 0.18$ & $0.55 \pm 0.16$ \\
$\gamma$-Globulin & $0.33 \pm 0.05$ & $0.32 \pm 0.07$ & $0.21 \pm 0.04^{*}$ \\
Fibrinogen &
\end{tabular}

$* p<0.05$ compared to maternal values (one-way analysis of variance). 


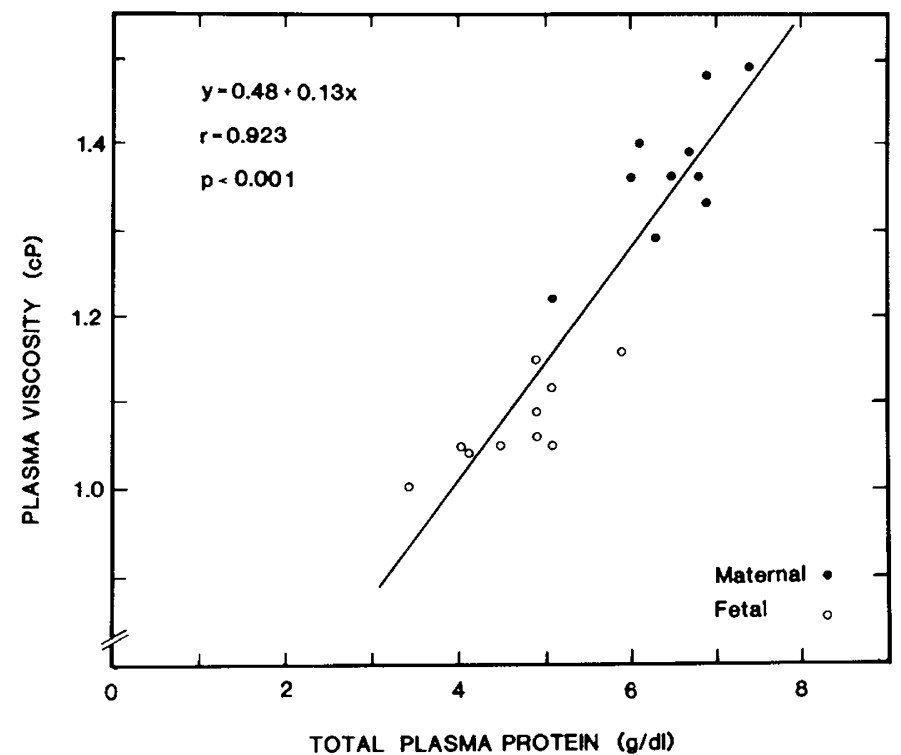

Fig. 4. Plasma viscosity (ordinate) plotted against total plasma protein concentration (abscissa) for maternal and fetal blood.

$P_{i} / P_{0}$ and $\mathrm{MCV}$ could be established (Fig. 5). The regression line yielded $y=2.22 x-181.88(r=0.909, p<0.001)$.

The computed relative resistance in a pore bearing a red cell to that in a pore with Ringer's solution alone $(\beta)$ was not different for large pores $(6.9 \mu \mathrm{m})$, slightly elevated with the intermediate pore size $(4.5 \mu \mathrm{m})$, and was over 3 times higher for the small 2.6 $\mu \mathrm{m}$ pores (Fig. 6). Although $\beta$ was much higher, fetal RBCs did not plug filter pores, for all sizes studied, to a greater extent than maternal RBCs. This was documented by the lack of any statistically significant difference in the slope of the pressure-time curve $\left(K_{1}\right)$. The $K_{1}$ values for maternal and fetal RBCs, respectively, were $34.1 \pm 13.1$ and $29.5 \pm 12.6 \mathrm{~min}^{-1}$ for $2.6 \mu \mathrm{m}$ pores, $1.5 \pm 1.7$ and $2.1 \pm 1.5 \mathrm{~min}^{-1}$ for $4.5 \mu \mathrm{m}$ pores, and $0.52 \pm 0.60$ and $0.55 \pm 0.44 \mathrm{~min}^{-1}$ for $6.9 \mu \mathrm{m}$ pores.

The viscosity of hemoglobin solutions at a concentration of $31 \mathrm{~g} / \mathrm{dl}$ at $25^{\circ} \mathrm{C}$ and a shear rate of $540 \mathrm{~s}^{-1}$ was $8.5 \pm 3.8 \mathrm{cP}$ for the mothers and $8.8 \pm 1.4 \mathrm{cP}$ for the newborns. The amount of fetal hemoglobin was determined in three newborns; it was 74.8 $\pm 5.8 \%$ of the total hemoglobin.

The morphology of fetal red cells showed some characteristic features. On the cell surface, crater-like membrane invaginations (pits) could be found (Fig. 7). These cells have been previously described as "pocked" erythrocytes of the neonates (16). The interior of the cells also showed abnormalities. A large amount of intracytoplasmatic vacuoles was seen (Fig. 8, top). In the four pairs of samples studied, such vacuoles were found in $37.3 \pm$ $1.8 \%$ of the fetal RBCs and $19.6 \pm 5.4 \%$ of the maternal RBCs $(n=150$ cells for each subject, $p<0.005)$. Specimens postfixed with ruthenium red as an extracellular marker showed that only about $1 \%$ of these vacuoles have a communication with the cell surface (vacuoles filled with ruthenium red). There were also longitudinal, slit-like intracytoplasmatic inclusions, which were generally parallel and close to the cell surface (Fig. 8, middle), but were ruthenium red negative. These membrane-coated structures were found more frequently in fetal than maternal red cells. Remnants of mitochondria were recognized by the presence of cristae (Fig. 8, bottom).

\section{DISCUSSION}

In this study, newborn cord blood viscosity and its major determinants, i.e. hematocrit, plasma viscosity, red cell deformation, and red cell aggregation (8), were investigated in a systematic manner. The results indicate that the cord blood of the newborn has a whole blood viscosity which is not higher than that of the simultaneously obtained maternal blood. This is

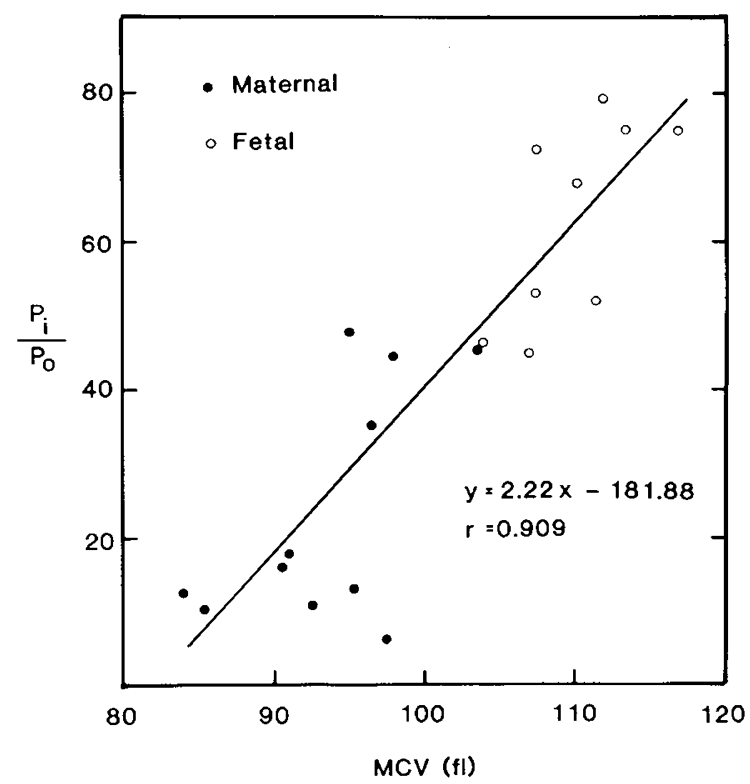

Fig. 5. The relationship between the ratio $P_{i} / P_{0}$ for Nuclepore filters with a mean pore diameter of $2.6 \mu \mathrm{m}$ (ordinate) and MCV (on abscissa). $P_{i}$ is the initial filtration pressure generated by pumping a red cell suspension through a filter; $P_{0}$ is the corresponding value obtained for Ringer's solution alone. The ratio $P_{i} / P_{0}$ is an expression of the resistance to filtration of the red cells present in the suspension. A positive correlation between the two variables can be seen.

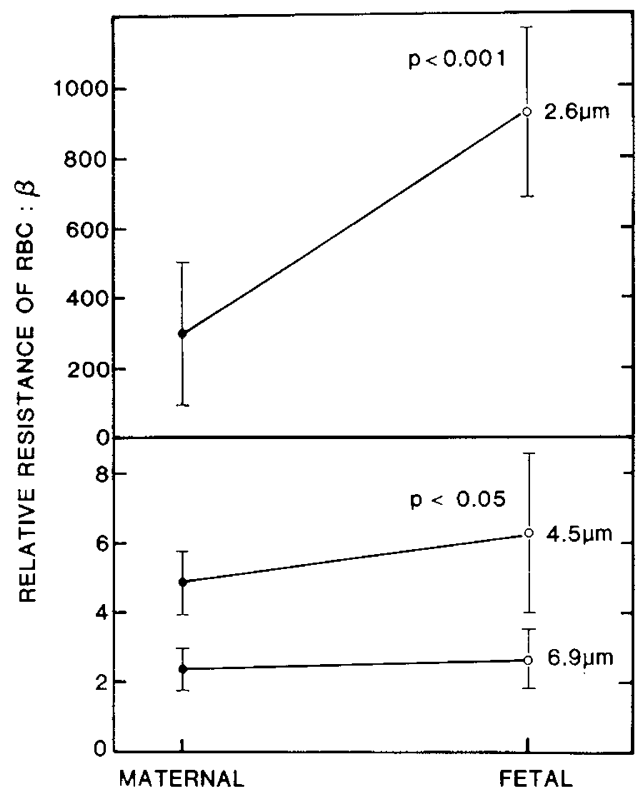

Fig. 6. Relative resistance in a pore containing a red cell to that in a pore with suspending medium alone, $\beta$, for maternal and fetal red cells (mean $\pm \mathrm{SD}, n=10$ ). Red cell filtration was performed with filter pores of $2.6,4.5$, and $6.9 \mu \mathrm{m}$ at a constant flow rate of $0.82 \mathrm{ml} / \mathrm{min}$.

surprising, since the hematocrit in the fetal blood $(47.0 \%)$ was considerably higher than that in the maternal blood $(35.5 \%)$. The fetal hematocrit found here is in agreement with other studies on cord blood $(5,23)$. When fetal and maternal blood samples were compared at the same hematocrit $\left(\eta_{\mathrm{P} 45}\right)$, the viscosity of fetal blood became significantly lower, by about $50 \%$ at shear rates below $1 \mathrm{~s}^{-1}$ and $20 \%$ at shear rates above $50 \mathrm{~s}^{-1}$.

One reason for the lower viscosity of fetal blood at the same hematocrit is the lower plasma viscosity. Plasma viscosity is mainly determined by plasma proteins. Fibrinogen is a major 

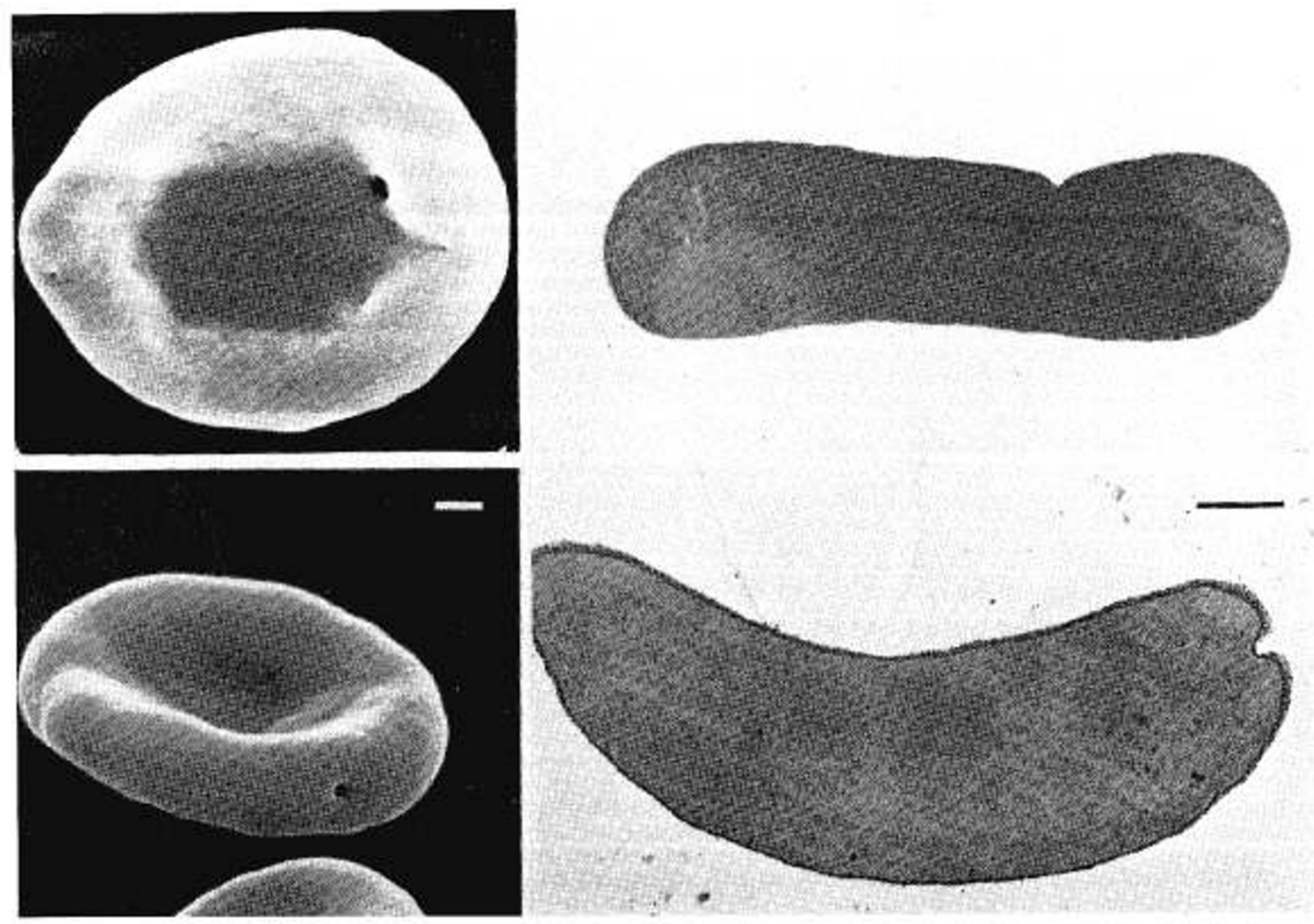

Fig. 7. Scanning electron microscopy $(l e f t, \times 6,800)$ and transmission electron microscopy pictures $($ right $, \times 12,900)$ of so-called "pocked" RBCs of the newborn. The invaginations can be located in the dimple area (top) or on the edge (bottom) of the cell. The bars represent $1 \mu \mathrm{m}$.
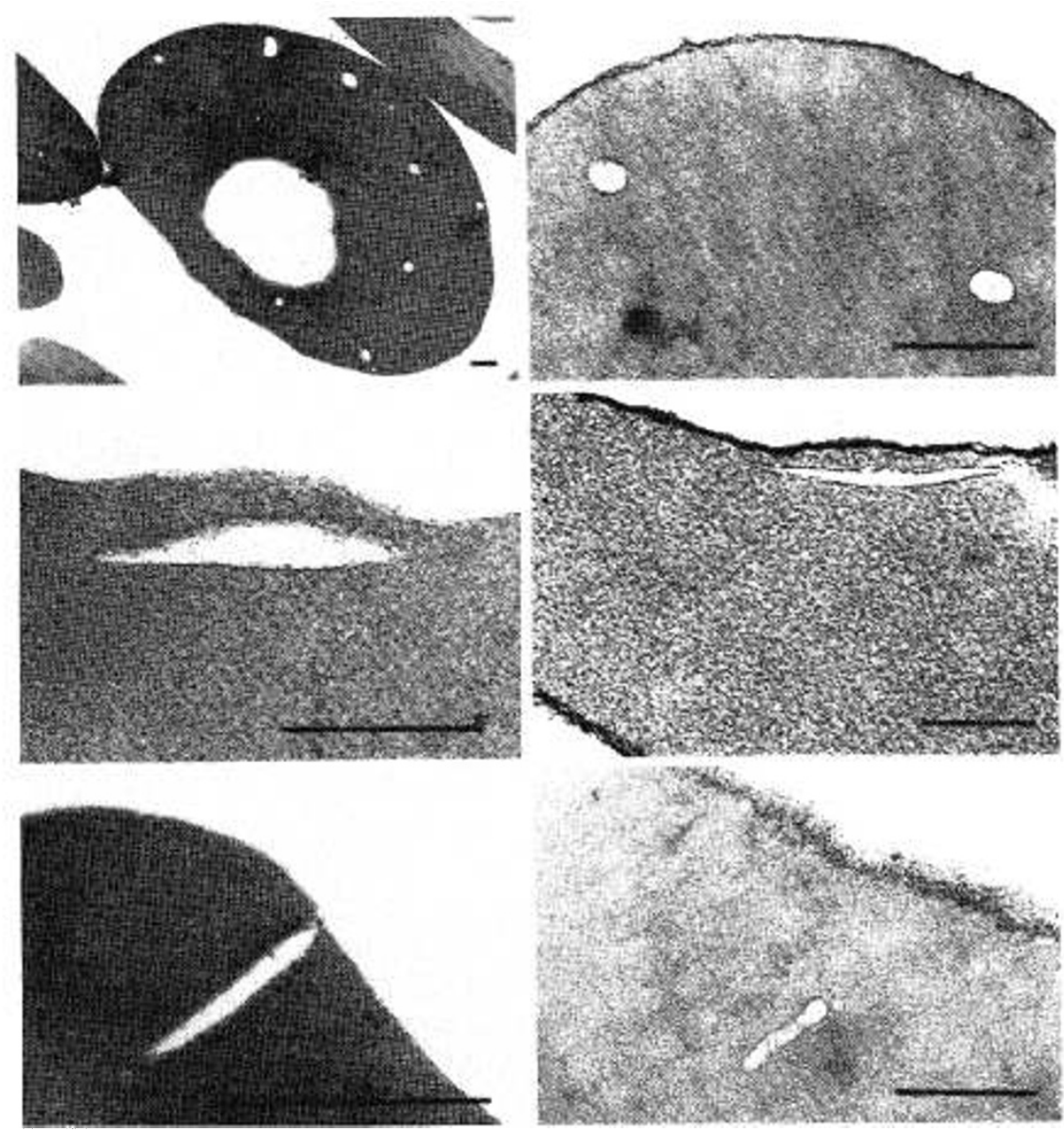

Fig. 8. Transmission electron microscopy pictures (between $\times 5,700$ and 60,000 ) showing ultrastructural details of fetal red cells. Cytoplasmatic vacuoles, often multiple (top), longitudinal structures parallel to the cell surface (middle), and elongated remnants of mitochondria containing cristae (bottom) can be seen. The samples on the right were postfixed with $0.1 \%$ ruthenium red as an extracellular marker, illustrating that these structures are not in connection with the cell surface. The bars represent $0.5 \mu \mathrm{m}$. 
determinant of plasma viscosity, and newborns clearly had lower fibrinogen levels. The fibrinogen concentration in mothers are lower than those reported in the literature $(22,27)$. Fibrinogen levels can fluctuate considerably during delivery within minutes (27), which may explain the difference between our study and those reports. Fibrinogen is involved in red cell aggregation, which occurs mainly at low shear rates (8). The low fibrinogen concentrations in newborns thus explain their lower blood viscosity at low shear rates. The facts that all plasma protein fractions correlate with plasma viscosity and that the total protein concentration gives the best correlation indicate that several fractions can contribute to the plasma viscosity.

When the plasma proteins were removed and washed red cells were suspended in Ringer's solution $\left(\eta_{\mathrm{R} 45}\right)$, the low viscosity of fetal blood at low shear rates was abolished or even partially reversed. At high shear rates, $\eta_{\mathrm{R} 45}$ was lower in the newborns. One reason for that could be the slightly lower MCHC of fetal $\mathrm{RBCs}$, since the hemoglobin concentration is a major determinant of the intracellular viscosity, which may play an important role in determining blood viscosity at high shear rates (8). The viscosity of hemoglobin solutions at the same concentration, however, was not significantly different for mothers and newborns. In agreement with the literature (31), we found that $75 \%$ of hemoglobin in full term newborns is fetal hemoglobin, which has two $\gamma$-chains instead of two $\beta$-chains. This difference does not seem to influence the hemoglobin viscosity to a noticeable degree. Studies on the viscosity of fetal hemoglobin have not been reported to our knowledge.

Data on blood viscosity in newborns are controversial $(3,11$, $21,31)$. Our results support the very recent discovery of Riopel et al. (31) that, under normal conditions, blood viscosity is lower in the neonatal period because of a lower plasma viscosity. This has now been confirmed also for the newborn lamb and adult sheep (32). Earlier reports described an increased whole blooa viscosity in normal newborns $(3,11,21)$. Those studies were done with a Wells-Brookfield viscometer, which has a different geometry than the viscometer used in this study. The fetal hematocrit was higher in all those studies, which might be due to the fact that blood was drawn from the placenta after delivery $(3,11)$ or from the newborn after delivery $(21)$, where hematocrit is regularly about $60 \%(3,23)$. It is likely that the higher hematocrit accounts for the difference in whole blood viscosity between these earlier reports and the present data. In these earlier studies, other determinants of whole blood viscosity were either not measured (red cell deformability) or were similar to our data (plasma viscosity and red cell aggregation; Ref. 11), and there were no comparisons of the viscosity of red cell suspensions in plasma and Ringer's solution at the same hematocrit between mothers and newborns.

A decreased deformability of fetal erythrocytes has been reported (14) by using nominal $3-\mu \mathrm{m}$ pore filters and a very high constant filtration pressure $(60 \mathrm{~mm} \mathrm{Hg})$. We extended such investigations to different sizes of filter pores. The resistance to passage through the narrow pores $(2.6 \mu \mathrm{m})$ is significantly higher for fetal RBCs, is nearly the same through $4.5-\mu \mathrm{m}$ pores, and is not different through $6.9-\mu \mathrm{m}$ pores. Narrow pores are more sensitive to changes in cell volume, while large pores are more sensitive to changes in internal viscosity (29). Our results therefore suggest that the decreased deformability of fetal red cells is mainly due to their increased volume. We found a $24 \%$ increase in volume, which is in agreement with Linderkamp et al. (20). The minimum cylindrical volume of fetal red cells, i.e. the thinnest cylinder through which a red cell can pass, was reported to be $8 \%$ higher than for maternal RBCs (20), others found it to be normal (6). Recently, Linderkamp et al. (19) measured the deformability of neonatal red cells with a rheoscope, where the cell volume or geometry is not important. They found no difference in the deformability of fetal and maternal RBCs, which agrees well with our data on $6.9-\mu \mathrm{m}$ pores, where the influence of the cell geometry is minimal (29). The fact that fetal RBCs do not plug the filter pores to a greater extent than maternal cells further supports the hypothesis that fetal red cells differ from adult cells in volume rather than in membrane or cytoplasm properties. The larger cell volume creates a higher initial filtration pressure, but thereafter the same fractions of maternal and fetal cells are able to pass the filter per unit time. The data with 4.5$\mu \mathrm{m}$ filters suggest that the fetal cells have reached a volume which might contribute to the flow resistance through the capillary bed with a diameter of $4-5 \mu \mathrm{m}$. Any additional decrease in red cell deformability such as severe acidosis (14) could therefore impair the microcirculation of the newborn.

The 3-fold increase in resistance for a fetal red cell to pass a 2.6- $\mu \mathrm{m}$ pore suggests that passage through splenic sinuses would be difficult for these cells, and one would expect a decreased survival of fetal red cells. In fact, a mean survival of 60-80 days (normal, 120 days) has been reported (26). The presence of membrane invaginations and intracytoplasmatic vacuoles in fetal red cells has been discribed $(4,16)$. Since the same type of red cells is found in adults after splenectomy (18) or in children with congenital agenesis of the spleen (12), their presence in the newborn reflects a functional hyposplenism during the intrauterine life (1), which may be due to splenic immaturity, decreased blood flow through the spleen, or a combination of both. This explains why such large and less deformable red cells are circulating in the peripheral blood at birth instead of having been removed by the spleen during intrauterine life. After birth, the number of these "pocked" erythrocytes gradually decreased within 2 months (16), indicating the maturation of the splenic function and/or increased blood flow to the spleen. We would also expect a reduction of the MCV with a resulting improvement of the filterability through small pores during that time.

In conclusion, fetal blood has two major disadvantages from a rheological point of view: the high cell concentration and the large red cell volume. These disadvantages are counterbalanced in vivo by the low plasma viscosity and probably reduced red cell aggregation. However, this balance can be disturbed during the perinatal period. Extremely high hematocrits are present in infants with intrauterine growth retardation, infants of diabetic mothers, certain chromosomal abnormalities, chronic intrauterine hypoxia, twin-to-twin transfusions, or large placental transfusions with delayed cord clamping. High fetal fibrinogen concentration, which can be regarded as normal for adults, may contribute to such inbalance. Newborns with infections due to maternal contamination were found to have a $100 \%$ increase of fibrinogen level within the first $48 \mathrm{~h}$ of life (30). These changes may overcome the natural protection of the neonatal circulation and lead to the hyperviscosity syndrome in the newborn.

Acknowledgments. The authors wish to thank D. Igals, G. Norwich, and H. O'Sullivan for their excellent technical assistance.

\section{REFERENCES}

1. Acevedo G, Maurer AM 1963 The capacity for removal of erythrocytes containing Heinz bodies in premature infants and patients following splenectomy. J Pediatr 63:61-64

2. Amit M, Camfield PR 1980 Neonatal polycythemia causing multiple cerebral infarcts. Arch Neurol 37:109 110

3. Bergqvist G 1974 Viscosity of the blood in the newborn infant. Acta Paediatr Scand 63:858-864

4. Blanton PL, Martin J, Haberman S 1968 Pinocytotic response of circulating erythrocytes to specific blood grouping antibodies. J Cell Biol 37:716-728

5. Bowe ET, Beard RW, Finster M, Pojpers PJ, Adamson K, James LS 1970 Reliability of fetal blood sampling. Am J Obstet Gynecol 107:279-287

6. Canham PB. Burton AC 1968 Distribution of size and shape in populations of normal human red cells. Circ Res 22:405-522

7. Chien S, Usami S, Dellenback RJ, Bryant CA 1971 Comparative hemorheology-hematological implications of species differences in blood viscosity. Biorheology 8:35-57

8. Chien S 1975 Biophysical behavior of red cells in suspension. In: MacN.Surgenor D (ed) The Red Blood Cell, Academic Press, New York, pp $1031-1133$

9. Chien S, King RG, Kaperonis AA, Usami S 1982 Viscoelastic properties of sickle cells and hemoglobin. Blood Cells 8:53-64 
10. Chien S, Schmalzer EA, Lee MML, Impelluso T, Skalak R 1983 Role of white blood cells in filtration of blood cells suspensions. Biorheology 20:11-27

11. Gaehtgens P, Schickendantz S 1975 Rheological properties of maternal and neonatal blood. Bibl Anat 13:107-108

12. Gasser C, Willi H 1952 Spontane Innenkoerperbildung bei Milzagenesie. Helvet Paediatr Acta 7:369-382

13. Gatti RA, Muster AJ, Cole RB, Paul MH 1966 Neonatal polycythemia with transient cyanosis and cardio-respiratory abnormalities. J Pediatr 69:10631072

14. Gross GP, Hathaway WE 1972 Fetal erythrocyte deformability. Pediatr Res 6:593-599

15. Hakanson DO, Oh W 1977 Necrotizing enterocolitis and hyperviscosity in the newborn infant. J Pediatr 90:458-461

16. Holroyde CP, Oski FA, Gardner FH 1969 The pocked erythrocyte. Red cell surface alterations in reticuloendothelial immaturity of the neonate. $\mathrm{N}$ Engl J Med 281:516-520

17. Holroyde CP, Gardner FH 1970 Acquisition of autophagic vacuoles by human erythrocytes. Physiological role of the spleen. Blood 36:566-575

18. Kent G, Minick OT, Volini FI, Orfei E 1966 Autophagic vacuoles in human red cells. Am J Pathol 48:831-857

19. Linderkamp O, Wu PYK, Meiselman HJ 1982 Deformability of density separated red blood cells in normal newborn infants and adults. Pediatr Res 16:964-968

20. Linderkamp O, Wu PYK, Meiselman HJ 1983 Geometry of neonatal and adult red blood cells. Pediatr Res 17:250-253

21. Macintosh TF, Walker CHM 1973 Blood viscosity in the newborn. Arch Dis Child 48:547-553

22. Markarian M, Jackson JJ 1968 Comparison of the kinetics of clot formation, fibrinogen, fibrinolysis, and hematocrit in pregnant women and adults. Am J Obstet Gynecol 101:593-602

23. Matoth Y, Zaizov R, Varsano I 1971 Postnatal changes in some red cell parameters. Acta Paediatr Scand 60:317-323

24. Mentzer WC 1978 Polycythaemia and the hyperviscosity syndrome in newborn infants. Clin Haematol 7:63-74

25. Neuhausen BS, Rioch DM 1923 The refractometric determination of serum proteins. J Biol Chem 55:353-356

26. Pearson HA 1967 Life-span of the fetal red blood cells. J Pediatr 70:166-171

27. Ratnoff OD, Colopy JE, Pritchard JA 1954 The blood-clotting mechanism during normal parturition. J Lab Clin Med 44:408-415

28. Ratnoff OD, Menzie C 1951 A new method for the determination of fibrinogen in small samples of plasma. J Lab Clin Med 37:316-320

29. Reinhart WH, Chien S 1983 Effects of osmolality on red cell deformability. Physiologist 26:A-107

30. Relier JP, de Gamarra E, de Bethmann O, Savaglio N, Minkowski A 1976 Interet de la mesure du taux de fibrinogene dans les infections neonatales par contamination maternelle. Arch Fr Pediatr 33:109-120

31. Riopel L, Fouron JC, Bard H 1982 Blood viscosity during the neonatal period: the role of plasma and red blood cell type. J Pediatr 100:449-453

32. Riopel L, Fouron JC, Bard H 1983 A comparison of blood viscosity between the adult sheep and newborn lamb. The role of plasma and red blood cell type. Pediatr Res 17:452-455

33. Rosenkrantz TS, Oh W 1982 Cerebral blood flow velocity in infants with polycythemia and hyperviscosity: effects of partial exchange transfusion with Plasmanate. J Pediatr 101:94-98

34. Skalak R, Impelluso T, Schmalzer EA, Chien S 1983 Theoretical modeling of filtration of blood cell suspensions. Biorheology 20:41-56

\title{
New Tools for the Study of Niemann-Pick Disease: Analogues of Natural Substrate and Epstein-Barr Virus-transformed Lymphoid Cell Lines
}

\author{
THIERRY LEVADE, ROBERT SALVAYRE, JEAN-CLAUDE BES, MEYER NEZRI, AND \\ LOUIS DOUSTE-BLAZY
}

Laboratoire de Biochimie Médicale (Faculté de Médecine Purpan) and INSERM U 101, Biochimie des Lipides,

Toulouse, France [T.L., R.S., L.D.B.], Laboratoire de Biologie Médicale (Faculté de Médecine Purpan)

Toulouse, France [J.C.B.], and Service de Pédiatrie, Centre Hospitalier d'Aix en Provence, France [M.N.]

\begin{abstract}
Acid sphingomyelinase activity was determined in Epstein-Barr virus-transformed lymphoid cell lines (LCL) established from patients affected with Niemann-Pick disease (NPD) using several substrates: sphingomyelin derivatives, radiolabeled $\left[{ }^{14} \mathrm{C} /\right.$ sphingomyelin (SM), fluorescent $N$-(10-(1-pyrene)decanoyl)sphingomyelin $\left(\mathrm{P}_{10}-\mathrm{SM}\right)$ or colored trinitrophenylaminolaurylsphingomyelin, and the chromogenic non-natural substrate 2- $N$-(hexadecanoyl)amino-4-nitrophenylphosphoryl-choline. LCL from NPD Type A and Type B showed a severe deficiency of acid sphingomyelinase determined using either substrate, whereas LCL from normal subjects had
\end{abstract}

Received March 7, 1984: accepted June 22, 1984.

Requests for reprints should be addressed to Dr. Thierry Levade, Laboratoire de Biochimie Médicale, Faculté de Médecine Purpan, 37, Allées Jules Guesde, 31000 Toulouse, France.

This research was supported by grants from Institut National de la Santé et de la Recherche Médicale and from Université Paul Sabatier, Toulouse, France. an activity close to that of blood leukocytes. Sphingomyelinase in normal LCL had the same $\mathrm{pH}$ optimum (5.0-5.2) and molecular form (pI 5.8) as the enzyme from other sources; identical profiles and activity levels were obtained using the various analogues of sphingomyelin. However, among these derivatives, the assay using $\mathrm{P}_{10}-\mathrm{SM}$ appeared as the most useful and sensitive for enzymatic diagnosis of NPD. Electron microscopy of NPD LCL demonstrated the lysosomal storage. These results prove the validity of $\mathrm{LCL}$ as an experimental model system for NPD. (Pediatr Res 19:153-157, 1985)

\section{Abbreviations}

LCL, lymphoid cell lines

NPD, Niemann-Pick disease

SM, sphingomyelin

$\mathrm{P}_{10}-\mathrm{SM}, \mathrm{N}-(10-(1-p y r e n e) d e c a n o y l)$ sphingomyelin 